\title{
THE CORRELATIONS AMONG CONSTRUCTS IN THE HEALTH BELIEF MODEL AND SELF-EFFICACY IN APPLYING THE NEWLY DEVELOPED INDONESIAN MODEL OF ASSERTIVE COMMUNICATION (CERDAS)
}

\author{
Theresia Puspitawati ${ }^{1^{*}}$, Yayi Suryo Prabandari ${ }^{2}$, \\ Soenarto Sastrowijoto ${ }^{3}$, Ira Paramastri ${ }^{4}$, Mora Claramita ${ }^{3,5}$ \\ ${ }^{1}$ Department Public Health, Faculty of Health Science, Universitas Respati Yogyakarta \\ ${ }^{2}$ Department Health Behaviour Environment Health and Social Medicine, \\ Faculty of Medicine, Universitas Gadjah Mada \\ ${ }^{3}$ Department of Medical Education and Bioethics Faculty of Medicine, Universitas Gadjah Mada \\ ${ }^{4}$ Faculty of Psychology, Universitas Gadjah Mada \\ ${ }^{5}$ Department of Family and Community Medicine, Faculty of Medicine, Universitas Gadjah Mada
}

Accepted: 5 February 2018

*Correspondence:

Theresia Puspitawati

Department Public Health, Faculty of Health Science, Universitas Respati Yogyakarta,

Jl. Raya Tajem Km 15, Maguwoharjo, Depok, Sleman, DIY

Email: thpuspitawati@gmail.com

Copyright: (C) the author(s), YCAB publisher and Public Health of Indonesia. This is an open-access article distributed under the terms of the Creative Commons Attribution Non-Commercial License, which permits unrestricted non-commercial use, distribution, and reproduction in any medium, provided the original work is properly cited.

\begin{abstract}
Background: One of the most important factors in providing health services is communication. Effective communication between patient-physician will have an impact on health outcomes. Nevertheless, a gap still occurs in patient-physician communication.

Objective: This study aimed to determine the correlation between the core concepts of the well-established Health Belief Model: perceived susceptibility, perceived severity, perceived benefits, perceived barriers and cues to action with the concept of self-efficacy in applying the newly developed Indonesian Model of Assertive Communication called "CERDAS".

Methods: A cross sectional study was conducted with 202 eligible women of the Family Welfare Programme in Yogyakarta, Indonesia. The samples were selected using quota sampling. Data were analyzed using Pearson correlation test.

Results: Results of the Pearson correlation tests between self efficacy and perceived susceptibiliy showed r: 0.191, perceived severity r: 0.239 , perceived benefits $\mathrm{r}$ : 0.256 , perceived barriers $\mathrm{r}$ : 0.272 , and cues to action $\mathrm{r}$ : 229 ; with all values $p<0.05$.

Conclusion: There was a significant correlation between perceived vulnerability, perceived severity, perceived benefits and perceived barriers, as well as cues to action with self-efficacy in applying the new Model of Assertive PatientPhysician Communication, "CERDAS".
\end{abstract}

Key words: assertive communication, patient, HBM, CERDAS

\section{INTRODUCTION}

A strong and open patient-physician communication is the main component in the process of providing effective health services (Ha \& Longnecker, 2010). An in-depth understanding of the patient or user of health services about the disease suffered as well as the care received will bring a positive impact (Rollnick, Heather, \& Bell, 1992). Previous research shows that there is a clear connection between patient-physician communication with 
the outcome of health care. Discussion in existing research and evidence from current data demonstrate that there is a strong correlation between effective patient-physician communication and improved health outcomes (Stewart, 1995). However, most studies emphasize the role of the health care provider, physician or nurse, while few researches stress the importance of the role of the patient in patient-physician communication (Williams, Weinman, \& Dale, 1998).

The Assertive Communication Model called "CERDAS" (Indonesian for smart) is an alternative model of patient-physician communication with the framework recently developed based on patients' perspectives during a study conducted in Yogyakarta. The CERDAS model called is an abbreviation of three core concepts, namely: 1) 'cermat' (knowledgeable): patients must be careful to equip themselves with literacy and knowledge in accordance with the problems encountered when receiving advise from a physician; 2) 'berdaya' (empowered): one of the indicators of the assertive communication involves patients applying themselves, i.e. able to express what they feel is important; and 3) 'apresiatif' (appreciative): in assertive communication patients are expected to be effective in maintaining a healthy patientphysician relationship with communication based on sustainability (Puspitawati, 2017).

The Health Belief Model (HBM) is one of the best known and most well-established theories used in discussing the adoption process of health behavior. The HBM model is used to predict health behaviour through the patient's perception of disease or strategies to prevent it (Hayden, 2017).

This study aimed to determine the correlation of each concept of HBM, specifically, perceived suceptibility, perceived severity, perceived benefits, perceived barriers, cues to action with the concept of self-efficacy in applying the patient-physician Assertive Communication Model called "CERDAS".

\section{METHODS}

Study design and sample

This was a cross-sectional study. Samples were selected by quota sampling. Participants were from 20 subvillages and 200 neighbourhood associations. There were 202 eligible women from the Family Welfare Programme membership of Maguwoharjo Village, Depok Subdistrict, Sleman District, Yogyakarta Special Region. The study was conducted on April 2017.

\section{Instrument}

The questionnaire of Assertive Communication "CERDAS" consisted of 24 questions which included two questions about perceived susceptibility, three questions about perceived severity, four questions in terms of perceived benefits, two questions on perceived barriers, seven questions with respect to cues to action, and finally six questions about self-efficacy. Questions about model constructs were graded based on the following Likert scale: favourable statement: ' 5 ' =Strongly agree; ' 4 ' = agree; ' 3 ' $=$ neither agree nor disagree; ' 2 ' = disagree; and ' 1 ' strongly disagree; and unfavourable statement: ' 5 '= strongly disagree; ' 4 ' = disagree; ' 3 ' $=$ neither agree nor disagree; ' 2 ' $=$ agree; and ' 1 '= strongly agree. The research questionnaire was completed by the participants before training, and four weeks after the education intervention.

\section{Data analysis}

The collected data were analyzed using Pearson Correlation test with the significance level set at $p<0.05$.

\section{Ethical consideration}

The study received approval from the Medical and Health Research Ethics Committee (MHREC) of Faculty of Medicine Universitas Gadjah Mada-Dr. Sardjito General Hospital, Yogyakarta, Indonesia, Ref. No.: KE/FK/717/EC/2016. The researchers have confirmed that each respondent signed an appropriate informed consent. 


\section{RESULTS}

Characteristics of the respondents

As shown at Table 1, the respondents of the research were 202 participants. The largest number of respondents were in the age group of 45-55 years with 82 respondents (40.6\%). As for the level of education, the majority had middle educational background with 128
(59.3\%). And most of participants worked as housewife with $169(80.7 \%)$. The results of mean score of perceived susceptibility, perceived severity, perceived benefits, perceived barriers, cues to action and selfefficacy on the Assertive Communication Model "CERDAS" are shown in Table 2.

Table 1 Frequency distribution of demographic characteristics

\begin{tabular}{lrrr}
\hline $\begin{array}{c}\text { Demographic } \\
\text { Characteristic }\end{array}$ & Frequency (N) & & \% \\
\hline Age & & \\
$15-24$ & 5 & 2.5 \\
$25-34$ & 74 & 10.9 \\
$35-44$ & 82 & 36.3 \\
$45-55$ & 17 & 40.6 \\
$55-64$ & 2 & 8.4 \\
$\quad>65$ & & 2.0 \\
Education level & 49 & 22.7 \\
$\quad$ Primary & 128 & 59.3 \\
$\quad$ Middle & 25 & 11.6 \\
$\quad$ Diploma/Bachelor & & \\
Work status & 163 & 80.7 \\
$\quad$ Housewife & 39 & 19.3 \\
$\quad$ Worker & 202 & 100.0 \\
\hline Total & & \\
\hline
\end{tabular}

Table 2 The mean score of perceived susceptibility, perceived severiry, perceived benefits, perceived barriers, cues to action and self efficacy

\begin{tabular}{lrc}
\hline \multicolumn{1}{c}{ Variable } & Mean \pm SD & $\begin{array}{c}\text { Standar Error of } \\
\text { mean }\end{array}$ \\
\hline Perceived susceptibility & $7.34 \pm 1.550$ & 0.109 \\
Perceived severity & $11.65 \pm 1.952$ & 0.137 \\
Perceived benefit & $16.49 \pm 1.777$ & 0.125 \\
Perceived barrier & $7.29 \pm 1.462$ & 0.103 \\
Cues to action & $30.30 \pm 3.063$ & 0.216 \\
Self efficacy & $22.85 \pm 2.861$ & 0.201 \\
\hline
\end{tabular}

Table 3 shows the results of the Pearson Correlation analysis. The five main concepts of HBM were strongly correlated with the concept of self efficacy, i.e. perceived suceptibility with the value of $\mathrm{r}=0.191$, perceived severity with the value of $r=0.239$, perceived benefits with the value of $r=0.256$, perceived barriers with the value of $r=0.272$ and cues to action with the value of $r=0.229$. All $p$ values were $<0.05$ indicating significant correlations between core concepts. 
Table 3 The Pearson correlation analysis of perceived susceptibility, perceived severity, perceived benefit, perceived barrier and cues to action with self efficacy

\begin{tabular}{|c|c|c|}
\hline \multirow{2}{*}{$\begin{array}{l}\text { Variable } \\
\text { Perceived susceptibility }\end{array}$} & \multicolumn{2}{|c|}{ Self efficacy } \\
\hline & $\mathrm{r}$ & $0.191 * *$ \\
\hline & $p$ & 0.903 \\
\hline & $\mathrm{n}$ & 0.202 \\
\hline \multirow[t]{3}{*}{ Perceived severity } & $\mathrm{r}$ & $0.239 * *$ \\
\hline & $p$ & 0.001 \\
\hline & $\mathrm{n}$ & 0.202 \\
\hline \multirow[t]{3}{*}{ Perceived benefit } & $\mathrm{r}$ & $0.256^{* *}$ \\
\hline & $p$ & 0.000 \\
\hline & $\mathrm{n}$ & 0.202 \\
\hline \multirow[t]{3}{*}{ Perceived barrier } & $\mathrm{r}$ & $0.229 * *$ \\
\hline & $p$ & 0.001 \\
\hline & $\mathrm{n}$ & 0.202 \\
\hline \multirow[t]{3}{*}{ Cues to action } & $\mathrm{r}$ & $0.217 * *$ \\
\hline & $p$ & 0.000 \\
\hline & $\mathrm{n}$ & 0.202 \\
\hline
\end{tabular}

\section{DISCUSSION}

Pearson Correlation test results showed that the five main concepts of HBM: i.e. perceived susceptibility, perceived severity, the perceived benefit, perceived barrier and cues to action were significantlly correlated to the core concept of patients' self efficacy.

The correlation coefficient between the five HBM concepts which was the highest was the perceived barrier (r: 0.272). Patients find it is often not easy to express what they feel to doctors. The majority of respondents in this study are from the midde and lower education levels. Research has shown that the education factor is more influential than other factors such as age or income (Kim, Kols, Bonnin, Richardson, \& Roter, 2001). In this study the research setting is Javanese. Javanese culture emphasizes two primary rules of conduct. The first rule is to avoid conflict, while the second rule is to show an attitude of respect toward others (Geertz, 1989). It is therefore not easy for Javanese people to apply assertive communication. One of the elements of assertive communication includes directly expressing what one is feeling including negative reactions (Alberti \& Emmons, 2017; Lazarus, 1973; Rakos, 1991; Salter, 2004; Townend, 1993). But for Javanese customs and cultural expectations, traditionally it is extremely disrespectful to say something negative or directly express the feeling of 'mboten' (no) (Magnis-Suseno, 1984).

This research shows there is a correlation between the variable perceived benefit with self efficacy ( $r: 0.256)$. This result is in line with the results of the evaluation of the training process that shows that $100 \%$ of the participants have never followed a training with material about assertive communication and all agreed that the training was very useful and meaningful. The respondents received information and developed a better understanding that if a patient does not implement the assertive communication, then the physician will not know their actual condition that is occurring in his/her body and that will have an impact in the decisionmaking and related actions. This predictament 
is an embodiment of the element of perceived severity (r: 239). It supports the idea that the participation of the respondents in the training has been growing along with the conviction of respondents in applying the assertive communication model called, CERDAS .

The implementation of cues to action (r: 229) is one of the means of conducting education interventions and providing information (Glanz, Rimer, \& Viswanath, 2008). The correlation between perceived susceptibiliy with self efficacy shows the lowest value of $r$ (r: 0.191). Perceived susceptibility in this case is the understanding of the respondents concerning their vulnerable condition if not applying the assertive communication. The respondents in this research are from the middle to lower socio-economic status. Typically, this strata of society tends to receive medical advice by not actively asking questions nor expressing their own opinions and they are usually not involved in making the medical decisions about actions to be taken (Willems, De Maesschalck, Deveugele, Derese, \& De Maeseneer, 2005).

The concept with the the highest correlation is perceived barrier (r: 0.272). The training of the Assertive Communication Model "CERDAS" managed to cultivate awareness and empower the patients building up patients' self-efficacy to become knowledgeable, empowered and appreciative. The realization of patient empowerment indicators include the incidence of self efficacy, increased knowledge and increased awareness of their behavior (Bravo et al., 2015). Patient empowerment is one of the important efforts to bring about the patient's participation in the health care service (Finset, 2017). The CERDAS Assertive Communication training in the context of the HBM involves cues to action as a strategy to grow the awareness by facilitating the availability of information (Rimer \& Glanz, 2005). This training is one of the strategies in exposing and providing better understanding to patients to form an ideal relationship with their physician. It is based on some previous researches which indicate a shift from traditional paternalistic to partnership approaches marked by more open discussions and negotiations in the decision-making process of medical treatment (Burke, 2008; Charles, Gafni, \& Whelan, 1997; Emanuel \& Emanuel, 1992). Today is the era of balancing the decision-making power between patientphysician. The patient-physician relationship is undergoing a revolution and evolution by the onset of shifting authority in taking decisionsmaking power from the physician and giving it more to the patient (Funnell et al., 1991; Truog, 2012; Veldhuijzen, 2011).

\section{Limitation of the study}

This research shows there was a significant correlation $(p<0.05)$ between perceived susceptibility, perceived severity, perceived benefit, perceived barrier and cues to action with self-efficacy, but the coefficient of association was still low. It is recommended that future research to strictly test of validity to develop more reliable instruments suitable for the unique settings and cultural contexts of the applied research using the CERDAS model.

\section{CONCLUSION}

This study revealed that the five concepts of HBM were correlated to self efficacy. Hence, by training with the Assertive Communication Model 'CERDAS" based on the HBM constructs, we can increase patients' perceived susceptibility, perceived severity, perceived benefit, perceived barrier and cue to action so that they are empowered and more knowledgeable to apply assertive communication when visiting and interacting with their physician.

\section{REFERENCES}

Alberti, R., \& Emmons, M. (2017). Your perfect right: Assertiveness and equality in your life and relationships: New Harbinger Publications.

Bravo, P., Edwards, A., Barr, P. J., Scholl, I., Elwyn, G., \& McAllister, M. (2015). Conceptualising patient empowerment: a mixed methods study. BMC Health Services Research, 15(1), 252.

Burke, S. E. (2008). The doctor-patient relationship: an exploration of trainee doctors' views. University of Birmingham. 
Charles, C., Gafni, A., \& Whelan, T. (1997). Shared decision-making in the medical encounter: what does it mean? (or it takes at least two to tango). Social Science and Medicine, 44(5), 681-692.

Emanuel, E. J., \& Emanuel, L. L. (1992). Four models of the physician-patient relationship. JAMA, 267(16), 2221-2226.

Finset, A. (2017). Patient Participation, Engagement and Activation: Increased emphasis on the role of patients in healthcare. Patient Education and Counseling, 100(7), 1245-1246.

Funnell, M. M., Anderson, R. M., Arnold, M. S., Barr, P. A., Donnelly, M., Johnson, P. D., . . . White, N. H. (1991). Empowerment: an idea whose time has come in diabetes education. The Diabetes Educator, 17(1), 37-41.

Geertz, H. (1989). The Javanese family: A study of kinship and socialization: Waveland Pr Inc.

Glanz, K., Rimer, B. K., \& Viswanath, K. (2008). Health behavior and health education: theory, research, and practice: John Wiley \& Sons.

Ha, J. F., \& Longnecker, N. (2010). Doctor-patient communication: a review. The Ochsner Journal, 10(1), 38-43

Hayden, J. A. (2017). Introduction to health behavior theory: Jones \& Bartlett Learning.

Kim, Y. M., Kols, A., Bonnin, C., Richardson, P., \& Roter, D. (2001). Client communication behaviors with health care providers in Indonesia. Patient Education and Counseling, 45(1), 59-68.

Lazarus, A. A. (1973). On assertive behavior: A brief note. Behavior Therapy, 4(5), 697-699.

Magnis-Suseno, F. (1984). Etika Jawa: sebuah analisa filsafi tentang kebijaksanaan hidup Jawa: Gramedia.

Puspitawati, T. (2017). Seminar Hasil Penelitian Model Komunikasi Asertif Pasien-Dokter: Department Public Health, Faculty of Health Science, Universitas Respati Yogyakarta.

Rakos, R. F. (1991). Assertive behavior: Theory, research, and training: Taylor \& Frances/Routledge.
Rimer, B. K., \& Glanz, K. (2005). Theory at a glance: a guide for health promotion practice.

Rollnick, S., Heather, N., \& Bell, A. (1992). Negotiating behaviour change in medical settings: the development of brief motivational interviewing. Journal of Mental Health, 1(1), 25-37.

Salter, A. (2004). Conditioned Reflex Therapy The Classic Book on Assertiveness That Begin Behavior Therapy: Selfhepl Books. com.

Stewart, M. A. (1995). Effective physician-patient communication and health outcomes: a review. CMAJ: Canadian Medical Association Journal, 152(9), 1423.

Townend, A. (1993). Developing assertiveness: Routledge.

Truog, R. D. (2012). Patients and doctors - the evolution of a relationship. New England Journal of Medicine, 366(7), 581-585.

Veldhuijzen, W. (2011). Challenging the patient centred paradigm: designing feasible guidelines for doctor patient communication: Maastricht university.

Willems, S., De Maesschalck, S., Deveugele, M., Derese, A., \& De Maeseneer, J. (2005). Socioeconomic status of the patient and doctorpatient communication: does it make a difference? Patient Education and Counseling, 56(2), 139-146.

Williams, S., Weinman, J., \& Dale, J. (1998). Doctorpatient communication and patient satisfaction. Family Practice, 15(5), 480-492.

Cite this article as: Puspitawati, $\mathrm{T}$., Prabandari, Y.S., Sastrowijoto, S., Paramastri, I., Claramita, M. (2018). The correlations among constructs in the health belief model and self-efficacy in applying the newly developed indonesian model of assertive communication (CERDAS). Public Health of Indonesia, 4(1):31-36. 